\title{
KEMAMPUAN TRANSLASI REPRESENTASI MATEMATIS SISWA KELAS VIII SMP dalam MENYELESAIKAN SOAL KONTEKSTUAL
}

\author{
Roby Zulianto $^{1 *)}$ \& Mega Teguh Budiarto ${ }^{2}$ \\ 1,2Universitas Negeri Surabaya
}

\section{INFO ARTICLES}

Article History:

Received: 05-06-2020

Revised: 23-06-2020

Approved: 23-06-2020

Publish Online: 27-06-2020

Key Words:

Translation, Mathematical

Representation, Contextual matters

This article is licensed under a Creative Commons AttributionShareAlike 4.0 International License.

\begin{abstract}
The aim of this qualitative research is to describe translation's ability of mathematic representation of junior high school students in solving contextual question. The research subjects were two students of class VIII at Junior High School 1 Ngoro, Jombang. Data collection techniques in this research were the assignment of translation mathematic representation, observation, and interview. Researchers as the main instrument of this research and used two research instrument, namely the assignment of translation mathematic representation and interview guidelines. Data analysis refers to indicators of translation ability of mathematic representation. Based on the results of research and discussion, it can be concluded that students can solve contextual question in two-way translation of visual to verbal representation, in two-way translation of symbolic to verbal representation, the translation of symbolic to visual representation. However, students have difficulty in solving contextual question on the translation of visual to symbolic representation.
\end{abstract}

\begin{abstract}
Abstrak: Penelitian kualitatif ini bertujuan mendeskripsikan kemampuan translasi representasi matematika siswa SMP dalam menyelesaikan soal kontekstual. Subjek penelitian adalah dua siswa kelas VIII di SMPN 1 Ngoro, Jombang. Teknik pengumpulan data yang digunakan adalah pemberian tugas translasi representasi matematis, observasi, dan wawancara. Peneliti sebagai instrumen utama dalam penelitian ini mengembangkan dua instrumen penilitian yaitu tugas translasi representasi matematis dan pedoman wawancara. Analisis data mengacu pada indikator kemampuan translasi representasi matematis. Berdasar pada hasil penelitian dan pembahasan, dapat disimpulkan bahwanya siswa dapat menyelesaikan soal kontekstual pada translasi dua arah representasi visual ke verbal, translasi dua arah representasi simbolik ke verbal, translasi representasi simbolik ke visual. Akan tetapi, siswa kesulitan dalam menyelesaikan soal kontekstual pada translasi representasi visual ke simbolik.
\end{abstract}

Correspondence Address: Tempuran RT/RW 012 Pundong village, Jombang, 61471, Indonesia; e-mail: robyzulianto@gmail.com

How to Cite (APA $6^{\text {th }}$ Style): Zulianto dan Budiarto. (2020). Kemampuan Translasi Representasi Matematis Siswa Kelas VIII SMP Dalam Menyelesaikan Soal Kontekstual. JKPM (Jurnal Kajian Pendidikan Matematika), 5 (2). 313 327.

Copyright: Zulianto dan Budiarto, (2020)

Competing Interests Disclosures: The authors declare that they have no significant competing financial, professional or personal interests that might have influenced the performance or presentation of the work described in this manuscript. 


\section{PENDAHULUAN}

Representasi memang sangat diperlukan untuk mengungkapkan berbagai konsep matematika yang abstrak. Representasi matematis (Fennell and Rowan, 2001; Fadillah, 2011; Arifin, 2017; Sandie, 2020) adalah "aktivitas berpikir dalam memproses informasi sehingga menghasilkan konsep atau mengomunikasikan ide-ide matematis dan menunjukkan hasil pemikiran tersebut baik secara visual, simbolik, maupun verbal". Hwang (dalam Arifin, 2017) dalam penelitiannya bahwa siswa dengan kemampuan pemecahan masalah yang tinggi dapat sangat terampil dalam melakukan translasi representasi bahasa, representasi gambar, dan representasi formal (kalimat, garis, dan rumus). Jenis representasi eksternal yang diungkapkan oleh Marliyanti dan Amin (2016) adalah representasi verbal yaitu membuat grafik atau tabel, representasi simbolik yaitu membuat model matematika, dan representasi verbal yaitu menyusun cerita sesuai dengan representasi yang disajikan. Jadi, peneliti menggolongkan representasi matematis yang digunakan dalam penelitian ini adalah (1) representasi visual yaitu representasi yang disajikan dalam bentuk gambar, diagram, grafik, atau tabel, (2) representasi simbolik yaitu representasi yang disajikan dalam suatu model matematis atau pernyataan matematis, (3) representasi verbal yaitu representasi yang disajikan dalam bentuk teks tertulis (Arifin, 2017).

Kemampuan representasi matematis merupakan salah satu indikator dalam tujuan pembelajaran matematika yang harus dimiliki siswa di Indonesia yakni menyajikan konsep dalam berbagai macam bentuk representasi matematis (tabel, grafik, diagram, gambar, sketsa, model matematika atau cara lainnya) seperti yang tercantum pada Peraturan Menteri Pendidikan dan Kebudayaan No. 58 Tahun 2014 tentang Kurikulum 2013 Matematika SMP (Kemdikbud, 2014). Selain pentingnya kemampuan representasi dalam tujuan pembelajaran matematika, Fennell and Rowan (2001) juga mengatakan bahwa "salah satu standar proses untuk pembelajaran matematika adalah representasi".

Kemampuan translasi representasi matematis adalah kecakapan siswa dalam mengubah suatu representasi matematis yang diberikan (representasi sumber) ke bentuk representasi matematis yang diminta (representasi target). "Dalam menyelesaikan masalah, siswa menganalisis informasi dari representasi sumber kemudian siswa menyelesaikan masalah tersebut dengan menggunakan representasi target yang diminta sesuai dengan kemampuan translasi representasi matematis mereka" (Marliyanti and Amin, 2016). Bossé, Adu-Gyamfi and Chandler (2014) mengungkapkan bahwa kemampuan siswa dalam melakukan proses translasi dapat berbeda-beda karena bergantung pada kemampuan translasi representasi yang dimiliki. Adapun proses translasi yang perlu diperhatikan (Bossé, Adu-Gyamfi and Chandler, 2014) yaitu (1) tahap membongkar sumber (unpacking the source) adalah mengungkapkan informasi yang terkandung di representasi sumber, (2) tahap koordinasi awal (preliminary coordination) adalah menentukan langkah awal pembentukan representasi target yang akan diinginkan, (3) tahap mengonstruk target (constructing the target) adalah menghasilkan atau membentuk representasi target yang diinginkan, dan (4) tahap menentukan kesetaraan (determining equivalence) adalah mempertimbangkan kesesuaian antara representasi sumber yang diberikan dengan representasi target yang dihasilkan.

Pentingnya kemampuan translasi representasi (Hidayati, Hudiono and Nursangaji, 2014; Monika, 2015; Arifin, 2017; Sandie, 2020) adalah kemampuan mendasar yang perlu dimiliki siswa untuk membangun konsep dan berpikir matematis serta dapat membantu siswa dalam menyelesaikan persoalanpersoalan matematika. Arifin (2017) meneliti kemampuan translasi antar-representasi matematika siswa MTs ditinjau dari gender, yang menunjukkan hasil penelitian siswa bergender feminime dan masculine sama-sama mampu melakukan semua translasi yang diberikan melalui tahap-tahap translasi. Selanjutnya, Hidayati, Hudiono and Nursangaji (2014) meneliti kemampuan translasi dan transformasi representasi dalam menyelesaikan soal persamaan linier satu variabel di SMP, yang menunjukkan bahwa kemampuan 
translasi siswa masih kurang, dikarenakan banyak siswa yang masih kesulitan dalam melakukan translasi yang diberikan dan masih jarang dialami siswa. Lebih lanjut, Monika (2015) meneliti kemampuan translasi representasi siswa materi himpunan di SMP, yang menunjukkan bahwa kemampuan translasi representasi matematis siswa termasuk dalam kategori kurang sekali, dikarenakan siswa cenderung belum paham materi yang telah diajarkan dan kurangnya pemahaman bentuk simbol, diagram dan verbal yang diberikan. Sandie (2020) meneliti tentang karakterisasi translasi representasi mahasiswa dalam menyelesaikan masalah kovariasional, yang hasil penelitiannya menemukan tiga karakteristik translasi representasi mahasiswa dalam memecahkan masalah kovariasional dan proses translasi representasi menggunakan keempat tahapan yaitu tahap membongkar sumber, tahap koordinasi awal, tahap mengonstruksi target, dan tahap menentukan kesetaraan.

Beberapa penelitian (Hidayati, Hudiono and Nursangaji, 2014; Monika, 2015; Arifin, 2017; Sandie, 2020) dengan penelitian ini memiliki kesamaan berupa penelitian terhadap kemampuan translasi representasi matematis siswa. Adapun perbedaan beberapa penelitian tersebut dengan penelitian ini adalah mengaitkan penyelesaian soal kontekstual oleh siswa SMP terhadap kemampuan translasi representasi matematis yang dimiliki siswa. Soal kontekstual adalah soal yang berkaitan dengan konteks yang menarik perhatian siswa dalam kehidupan sehari-hari. Penggunaan kontekstual dalam pembelajaran matematika, dapat mengembangkan kemampuan translasi representasi matematis siswa (Tandiseru, 2015). Berkaitan dengan hal tersebut maka siswa memiliki kemungkinan untuk mencoba berbagai macam representasi dalam menyelesaikan soal-soal matematika kontekstual. Kemudian materi yang disajikan pada soal kontekstual dalam penelitian ini yaitu materi himpunan, segitiga dan segiempat, persamaan linear dua variabel, persamaan garis lurus, dan teorema Pythagoras. Pada materi ini dapat digunakan sebagai translasi representasi matematis diantaranya representasi verbal, representasi simbolik, dan representasi visual. Penelitian ini bertujuan untuk mendeskripsikan kemampuan translasi representasi visual, simbolik, dan verbal pada siswa SMP dalam menyelesaikan soal kontekstual. Peneliti berharap hasil penelitian dapat membantu guru dalam merancang pembelajaran yang mampu mengembangkan kemampuan translasi representasi matematis dalam menyelesaikan soal kontekstual.

\section{METODE}

Penelitian ini termasuk jenis penelitian deskriptif dengan pendekatan kualitatif. Penelitian deskriptif ini bertujuan untuk mendeskripsikan kemampuan translasi representasi matematis pada siswa SMP dalam menyelesaikan soal kontekstual. Peneliti mempelajari kemampuan translasi representasi matematis siswa dengan mengacu pada indikator kemampuan translasi representasi pada Tabel 1. Indikator Kemampuan Translasi Representasi Matematis Siswa.

Tabel 1. Indikator Kemampuan Translasi Representasi Matematis Siswa

TAHAP TRANSLASI

Unpacking the source

\section{INDIKATOR}

1.1 Menyebutkan informasi yang terkandung dalam representasi sumber.

1.2 Menyebutkan representasi target yang diminta berdasarkan representasi sumber.
2.1 Menentukan strategi atau langkah awal pembentukan representasi target berdasarkan representasi sumber. 


\begin{tabular}{lc}
\hline Constructing the target & $\begin{array}{c}3.1 \text { Membentuk representasi target yang diminta sebagai penyelesaian dari } \\
\text { representasi sumber. }\end{array}$ \\
\hline Determining equivalence & $\begin{array}{c}4.1 \\
\text { Mempertimbangkan kembali kesesuaian representasi target dengan } \\
\text { representasi sumber. }\end{array}$ \\
\hline
\end{tabular}

Diadaptasi dari Arifin (2017)

Subjek dalam penelitian ini terdiri dari 2 siswa kelas VIII-F SMP Negeri 1 Ngoro, Jombang. Penentuan subjek dalam penelitian ini dengan menggunakan teknik purposive sampling, yaitu menentukan subjek penelitian dengan cara sengaja oleh peneliti berdasarkan kriteria atau pertimbangan tertentu (Faisal, 2007). Oleh karena itu, penentuan subjek penelitian tidak secara acak, tetapi dengan pertimbangan/rekomendasi dari Guru Matematika SMP Negeri 1 Ngoro, Jombang terhadap dokumen nilai ujian akhir semester ganjil kelas VIII dan kemampuan komunikasi yang baik. Adapun data yang diperoleh dari penelitian ini berasal dari siswa yang telah menerima materi himpunan, segitiga dan segi empat, persamaan linear dua variabel, persamaan garis lurus, dan teorema Pythagoras. Dari penentuan subjek penelitian tersebut, dipilihlah siswa yang berinisial NRM dan KJT dengan jenis kelamin yang sama.

Teknik pengumpulan data yang digunakan adalah pemberian tugas translasi representasi matematis, observasi, dan wawancara. Proses pengumpulan data diawali dengan observasi pada siswa dalam menyelesaikan tugas translasi representasi matematis yang selanjutnya dilaksanakan wawancara terhadap hasil penyelesaian tugas translasi representasi matematis tersebut. Instrumen pendukung dalam penelitian ini berupa tugas translasi representasi matematis dan pedoman wawancara sebagai alat untuk mengungkapkan kemampuan translasi representasi matematis dari subjek penelitian. Instrumen tugas translasi representasi matematis digunakan untuk mengukur kemampuan translasi representasi matematis siswa. Tugas ini dibuat berdasarkan soal kontekstual dengan materi segitiga dan segiempat, persamaan garis lurus, dan teorema Pythagoras. Tugas translasi representasi matematis terdiri atas 6 soal yang disusun berdasar pada 6 macam translasi representasi, yaitu translasi representasi visual ke verbal, translasi representasi visual ke simbolik, translasi representasi verbal ke visual, translasi representasi verbal ke simbolik, translasi representasi simbolik ke visual, dan translasi representasi simbolik ke verbal. Berikut kisi-kisi beserta tugas translasi representasi matematis.

Tabel 2. Kisi-Kisi Tugas Translasi Rrpresentasi Matematis Siswa

\begin{tabular}{|c|c|c|c|c|c|}
\hline \multirow{2}{*}{ No. } & \multirow{2}{*}{ Translasi } & \multicolumn{2}{|c|}{$\begin{array}{l}\text { Indikator Soal } \\
\end{array}$} & \multirow{2}{*}{ Materi Soal } & \multirow{2}{*}{$\begin{array}{l}\text { No. } \\
\text { Soal }\end{array}$} \\
\hline & & Representasi Sumber & Representasi Target & & \\
\hline 1. & $\begin{array}{l}\text { Translasi representasi } \\
\text { visual ke representasi } \\
\text { verbal }\end{array}$ & $\begin{array}{l}\text { Disajikan bangun segitiga } \\
\text { dan segiempat dengan } \\
\text { diketahui panjang sisi-sisi }\end{array}$ & $\begin{array}{l}\text { Menentukan luas } \\
\text { bangun datar yang } \\
\text { diarsir }\end{array}$ & $\begin{array}{l}\text { Segitiga dan } \\
\text { Segiempat }\end{array}$ & 1 \\
\hline 2. & $\begin{array}{l}\text { Translasi representasi } \\
\text { visual ke representasi } \\
\text { simbolik }\end{array}$ & $\begin{array}{l}\text { Disajikan grafik } \\
\text { persamaan garis lurus }\end{array}$ & $\begin{array}{l}\text { Menentukan } \\
\text { persamaan garis lurus }\end{array}$ & $\begin{array}{l}\text { Persamaan } \\
\text { Garis Lurus }\end{array}$ & 2 \\
\hline 3. & $\begin{array}{l}\text { Translasi representasi } \\
\text { verbal ke representasi } \\
\text { visual }\end{array}$ & $\begin{array}{l}\text { Diberikan soal kontekstual } \\
\text { tentang banyaknya anak } \\
\text { dalam suatu kelompok }\end{array}$ & $\begin{array}{l}\text { Menggambar diagram } \\
\text { Venn }\end{array}$ & Himpunan & 3 \\
\hline 4. & $\begin{array}{l}\text { Translasi representasi } \\
\text { verbal ke representasi } \\
\text { simbolik }\end{array}$ & $\begin{array}{l}\text { Diberikan soal kontekstual } \\
\text { tentang jumlah kendaraan } \\
\text { yang ditampung di tempat } \\
\text { parkir }\end{array}$ & $\begin{array}{l}\text { Menentukan sistem } \\
\text { persamaan linear dua } \\
\text { variabel }\end{array}$ & $\begin{array}{l}\text { Sistem } \\
\text { Persamaan } \\
\text { Linear Dua } \\
\text { Variabel }\end{array}$ & 4 \\
\hline
\end{tabular}




\begin{tabular}{|c|c|c|c|c|c|}
\hline \multirow{2}{*}{ No. } & \multirow{2}{*}{ Translasi } & \multicolumn{2}{|c|}{ Indikator Soal } & \multirow{2}{*}{ Materi Soal } & \multirow{2}{*}{$\begin{array}{l}\text { No. } \\
\text { Soal }\end{array}$} \\
\hline & & Representasi Sumber & Representasi Target & & \\
\hline 5. & $\begin{array}{l}\text { Translasi representasi } \\
\text { simbolik ke } \\
\text { representasi visual }\end{array}$ & $\begin{array}{l}\text { Diberikan suatu } \\
\text { persamaan garis }\end{array}$ & $\begin{array}{l}\text { Menggambar grafik } \\
\text { dari persamaan garis }\end{array}$ & $\begin{array}{l}\text { Persamaan } \\
\text { Garis Lurus }\end{array}$ & 5 \\
\hline 6. & $\begin{array}{l}\text { Translasi representasi } \\
\text { simbolik ke } \\
\text { representasi verbal }\end{array}$ & $\begin{array}{l}\text { Diberikan soal konteks } \\
\text { berupa pernyataan } \\
\text { simbolik panjang bangun } \\
\text { segitiga dan segiempat }\end{array}$ & $\begin{array}{l}\text { Menentukan keliling } \\
\text { bangun tersebut }\end{array}$ & $\begin{array}{l}\text { Segitiga dan } \\
\text { Segiempat }\end{array}$ & 6 \\
\hline
\end{tabular}

Tabel 3. Tugas Translasi Representasi Matematis

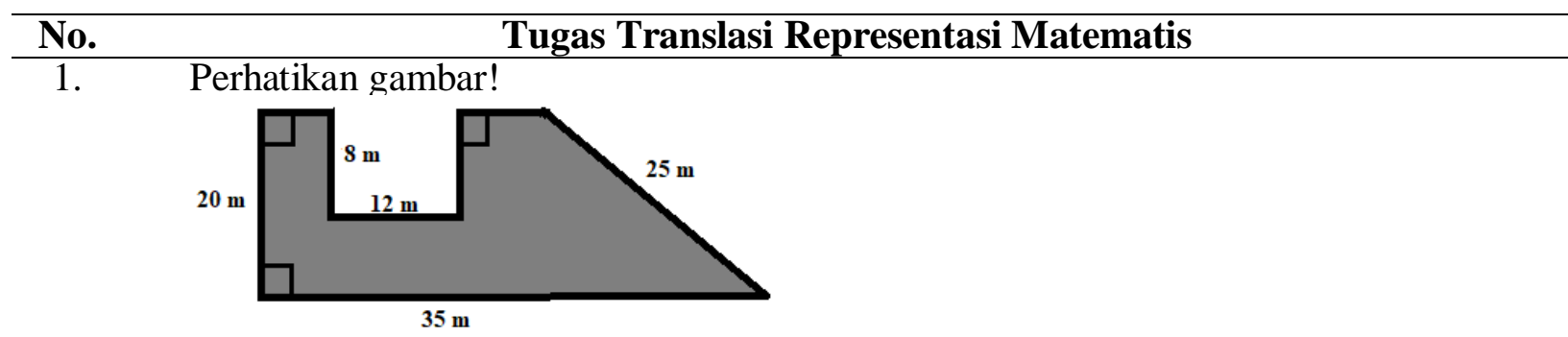

Daerah yang diarsir adalah sketsa tanah yang ditanami rumput. Hitunglah Luas hamparan rumput tersebut!

2. Seseorang telah bersepeda mengelilingi kota dengan jarak $90 \mathrm{~km}$ dalam waktu 6 jam dengan kecepaan konstan. Orang tersebut memberikan catatan grafik sebagai berikut.

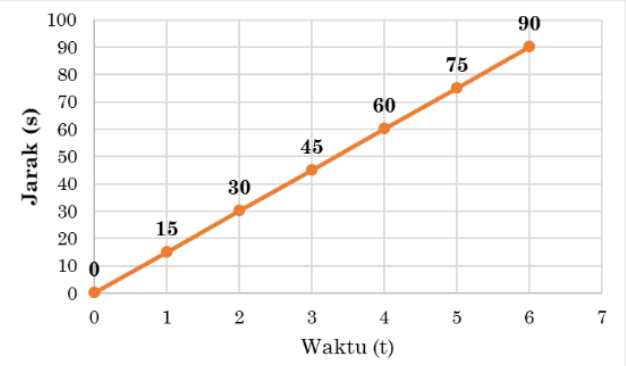

Dengan waktu (t) pada sumbu horizontal dan jarak (s) pada sumbu vertikal. Tentukan persamaan grafik tersebut!

3. Dari sekelompok anak, 15 anak gemar bermain bulu tangkis, 20 anak gemar bermain tenis meja dan 12 anak gemar bermain keduanya. Gambarkan dalam diagram Venn yang menyatakan hal tersebut! Berapakah banyak anak dalam kelompok tersebut?

4. Tempat parkir untuk motor roda dua dan mobil roda empat dapat menampung 3030uah kendaraan. Jumlah roda seluruh kendaraan 90 buah. Jika banyak motor dinyatakan dengan $x$ dan banyak mobil dinyatakan dengan $y$, tentukan sistem persamaan linear dua variabel dari pernyataan di atas!

5. Para ahli metrologi Indonesia menyiarkan informasi kepada warna negara bahwa harga beras per $\mathrm{kg}$ akan mengalami kenaikan dalam beberapa bulan kedepan, dengan ditunjukkan oleh suatu persamaan garis harga beras $y=3 x+12=3 x+12$ tkah kalian menggambar persamaan garis harga beras tersebut?

6. Taman berbentuk trapesium sama kaki dengan panjang sisi-sisi sejajar-nya $(x+$ 4) $m x+4) m(3 x+2) m 3 x+2)$ mjarak kedua garis sejajar $2 x m x$ mn luas taman 180 $m^{2}$. Tentukan keliling taman tersebut! 


\section{HASIL}

Soal yang digunakan dalam penelitian ini adalah soal kontekstual yang terdiri dari 6 soal berdasarkan 6 macam translasi representasi. Soal diberikan kepada subjek yang telah dipilih, yaitu NRM dan KJT. Berikut merupakan hasil penyelesaian soal kontekstual dan uraian wawancara oleh kedua subjek penelitian. Analisis Kemampuan Translasi Representasi Matematis Siswa (Subjek NRM)

1. Translasi Representasi Visual ke Verbal

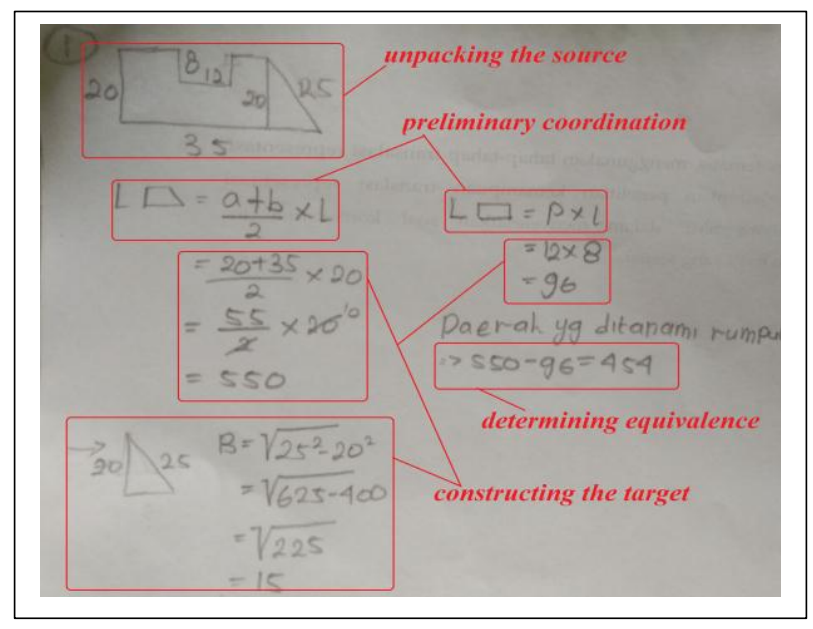

\section{Gambar 1. Jawaban NRM Soal Nomor 1}

Pada tahap unpacking the source, NRM menuliskan informasi awal yang terdapat pada gambar. Pada tahap preliminary coordinator, NRM menuliskan rumus untuk menentukan luas hamparan yang diarsir. Pada tahap constructing the target, NRM menentukan luas trapesium kemudian mengurangi dengan luas persegi panjang. Pada tahap determining equivalence, NRM yakin jawabannya sudah benar karena NRM sudah menghitung dengan tepat yakni luas trapesium yaitu 550 dikurangi dengan luas persegi panjang yaitu 96, sehingga hasil yang didapatkan $454 \mathrm{~m}^{2} 54 \mathrm{~m}^{\wedge} 2$.

2. Translasi Representasi Visual ke Simbolik

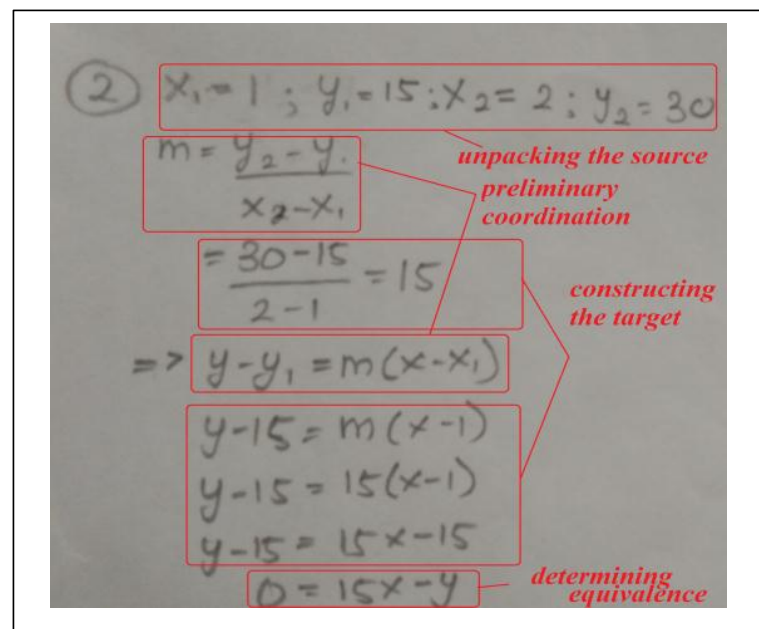

Gambar 2. Jawaban NRM Soal Nomor 2 
Pada tahap unpacking the source, NRM menuliskan informasi awal yang terdapat pada grafik yaitu titik koordinat $x_{1}=1, y_{1}=15, x_{2}=2, y_{2}=30$. Pada tahap preliminary coordinator, NRM menuliskan rumus untuk menentukan persaman grafik. Pada tahap constructing the target, NRM mensubstitusi $x_{1}=$ $1, y_{1}=15, x_{2}=2, y_{2}=30$ pada rumus untuk mencari nilai gradien yang kemudian nilai gradien dimasukkan pada $y-y_{1}=m\left(x-x_{1}\right)-y_{-} 1=m x-x_{-} 1$ sehingga didapatkan persamaan $0=15 x-$ $y=15 \mathrm{x}-\mathrm{y}$ tahap determining equivalence, NRM yakin jawabannya benar karena NRM telah menghitung dengan tepat berdasarkan rumus dan titik-titik yang diketahui.

3. Translasi Representasi Verbal ke Visual

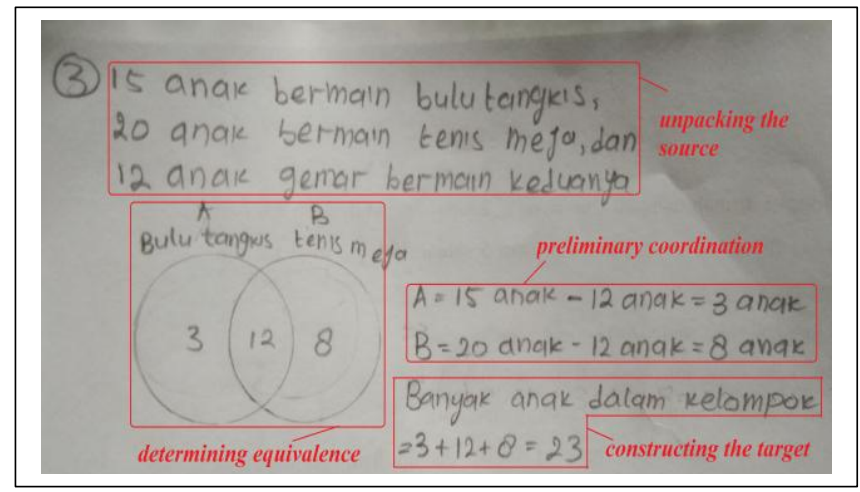

Gambar 3. Jawaban NRM Soal Nomor 3

Pada tahap unpacking the source, NRM menuliskan informasi 155 ak gemar bermain bulu tangkis, 200 ak gemar bermain tenis meja dan 122anak gemar bermain keduanya. Pada preliminary coordinator, NRM menggambar diagram Venn dan mencari banyak anak gemar bermain bulu tangkis saja itu dengan mengurangi banyak anak gemar bermain tenis meja dengan anak yang gemar bermain keduanya, sedangkan untuk mencari banyak anak gemar bermain tenis meja saja itu dengan mengurangi banyak anak gemar bermain tennis meja dengan anak gemar bermain keduanya. Kemudian mencari banyak anak dalam kelompok itu dengan menjumlahkan banyak anak gemar bermain tenis meja saja, banyak anak gemar bermain bulu tangkis saja, dan banyak anak gemar bermain keduanya. Pada tahap constructing the target, NRM menghitung banyak anak gemar bermain bulu tangkis saja $=15-12=3$ 15-12=3anyak anak gemar bermain tenis meja saja $=20-12=820-12=8$ anyak anak dalam kelompok tersebut $=3+8+$ $12=233+8+12=23$ Pada tahap determining equivalence, NRM yakin bahwa diagram Venn yang dibuat sudah benar. NRM telah menghitung dengan tepat sesuai bilangan-bilangan yang diketahui.

4. Translasi Representasi Verbal ke Simbolik

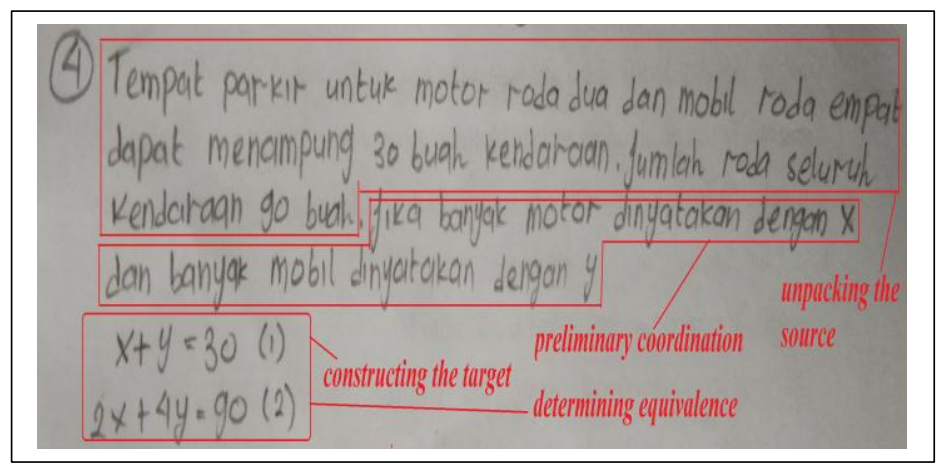

Gambar 4. Jawaban NRM Soal Nomor 4 
Pada unpacking the source, NRM menyebutkan informasi yang terdapat dalam soal yaitu tempat parkir untuk motor roda dua dan mobil roda empat dapat menampung 300buah kendaraan. Jumlah roda seluruh kendaraan 900 ah. Pada preliminary coordinator, NRM memisalkan $x$ sebagai motor roda dua dan $y$ sebagai mobil roda empat. Pada constructing the target, NRM menyebutkan $x+y=30+\mathrm{y}=30$ i pernyataan pertama, kemudian $2 x+4 y=90 x+4 y=90 \mathrm{i}$ pernyataan kedua. Pada tahap determining equivalence, NRM yakin bahwa kedua pernyataan sudah benar. Karena sudah sesuai dengan apa yang dinyatakan dalam soal.

5. Translasi Representasi Simbolik ke Visual

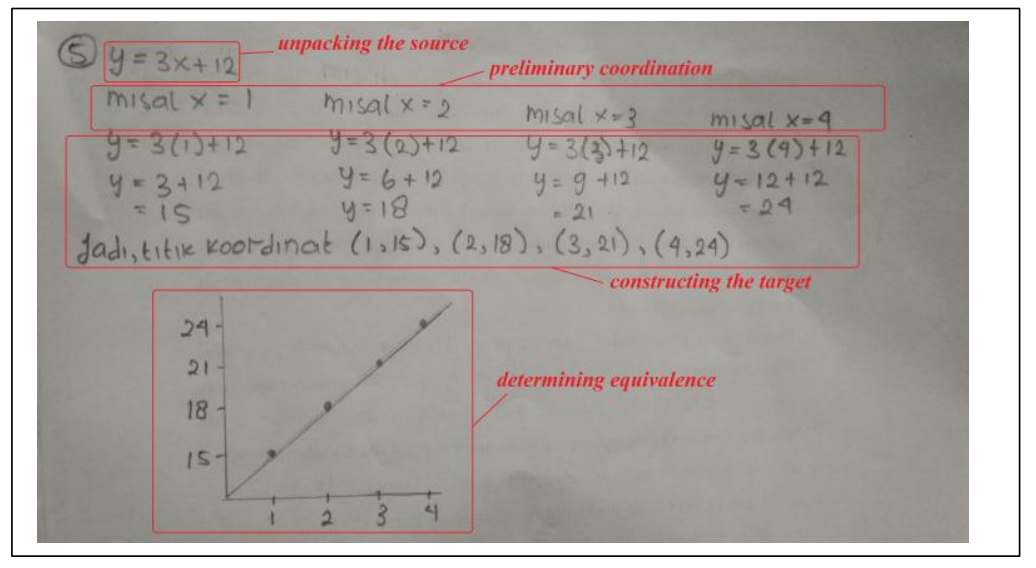

Gambar 5. Jawaban NRM Soal Nomor 5

Pada unpacking the source, NRM menuliskan informasi yang terdapat pada soal yaitu persamaan garis $y=3 x+12=3 \mathrm{x}+12$ preliminary coordination, NRM menuliskan pemisalan nilai $x$ engan $x=$ $1, x=2, x=3, x=4=1, \mathrm{x}=2, \mathrm{x}=3, \mathrm{x}=4$ dapatkan nilai $y$ ypada masing-masing pemisalan tersebut. Pada constructing the target, NRM mensubstitusikan nilai $x=1=1 \mathrm{e}$ dalam persamaan $y=3 x+$ $12=3 \mathrm{x}+12$ ngga didapatkan nilai $y=15=15$ ubstitusi nilai $x=2=2 \mathrm{e}$ dalam persamaan $y=3 x+$ $12=3 \mathrm{x}+12$ ngga didapatkan nilai $y=18=18$ ubstitusi nilai $x=3=3 \mathrm{e}$ dalam persamaan $y=3 x+$ $12=3 x+12$ ngga didapatkan nilai $y=21=21$ ubstitusi nilai $x=4=4 \mathrm{e}$ dalam persamaan $y=3 x+$ $12=3 x+12$ ngga didapatkan nilai $y=24=24$ emudian dapat diperoleh titik koordinat $(x, y) x, y)$ da tahap determining equivalence, NRM yakin bahwa grafik yang dibuat sudah benar karena titik koordinat $(1,15),(2,18),(3,21),(4,24) 1,15),(2,18),(3,21),(4,24)$ eroleh dari persamaan $y=3 x+12=3 x+12$

6. Translasi Representasi Simbolik ke Verbal

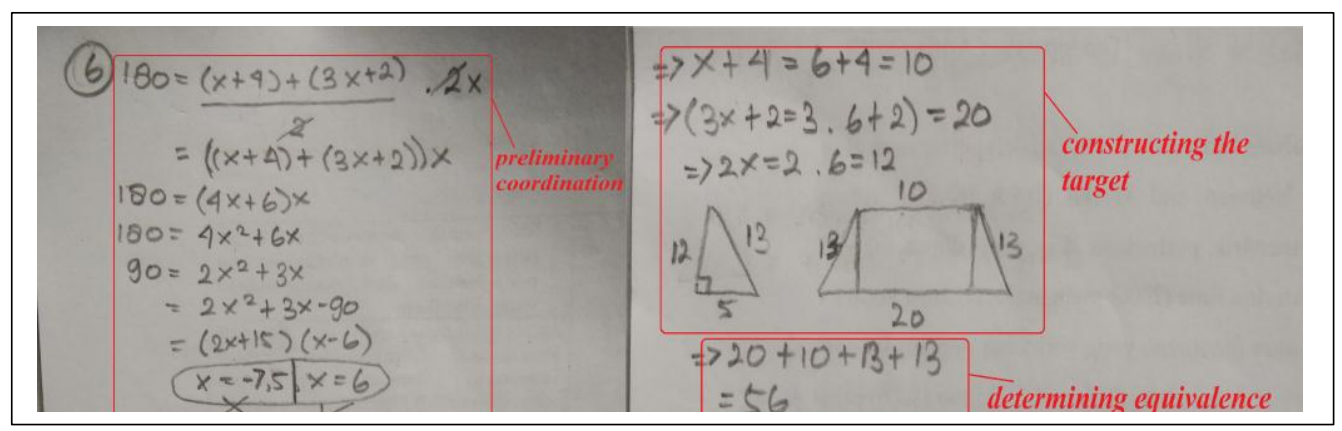

Gambar 6. Jawaban NRM Soal Nomor 6 
Pada tahap unpacking the source, NRM tidak menuliskan kembali informasi yang diketahui pada soal namun mengungkapkannya saat wawancara yaitu panjang sisi-sisi sejajar $(x+4) m x+4) \mathrm{m}(3 x+$ 2) $m 3 x+2) m$ kedua garis sejajar $2 x m 2 x$ mdan luas taman $180 m^{2} 80 \mathrm{~m}^{\wedge} 2$. Kemudian soal diminta untuk menentukan keliling taman berbentuk trapesium sama kaki. Pada tahap preliminary coordination, NRM mencari nilai $x$ ari luas taman kemudian menjumlahkan keempat sisi-sisi trapesium. Pada tahap constructing the target, NRM dapat menemukan nilai $x$ dari luas taman yaitu 6 yang kemudian substitusi nilai $x=6 \mathrm{x}=6(x+4) \mathrm{x}+4)$ asilnya 10 , substitusi nilai $x=6=6 \mathrm{e}(3 x+2) 3 \mathrm{x}+2)$ silnya 20 , substitusi nilai $x=6=6 \mathrm{e} 2 x \mathrm{x}$ n hasilnya 12 , selanjutnya mencari sisi miring trapesium dengan cara Pythagoras. Sehingga, panjang sisi-sisi trapesium 10,20,13,130, 20, 13, 13umlahkan dan keliling taman trapesium itu $56 \mathrm{~m}^{2} 6 \mathrm{~m}^{\wedge} 2$. Pada tahap determining equivalence, NRM yakin dengan jawabannya sudah benar karena NRM telah menghitung dengan tepat berdasarkan rumus dan bilangan-bilangan yang diketahui dari soal.

\section{Analisis Kemampuan Translasi Representasi Matematis Siswa (Subjek KJT)}

1. Translasi Representasi Visual ke Verbal

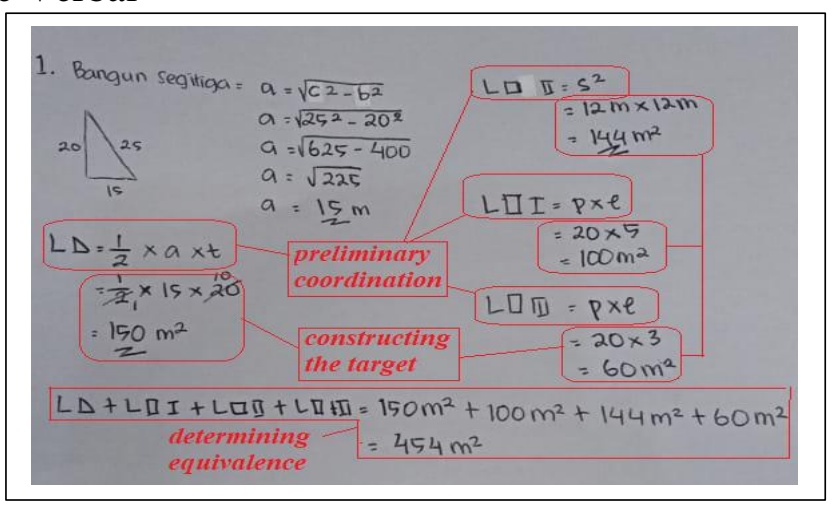

Gambar 7. Jawaban KJT Soal Nomor 1

Pada unpacking the source, KJT tidak menuliskan informasi awal yang terdapat pada gambar, namun KJT mengungkapkan informasi pada saat wawancara bahwa terdapat bangun segitiga, persegi, dan persegi panjang beserta sisi-sisinya. Pada preliminary coordinator, KJT menuliskan 4 rumus bangun datar yang harus dicari yaitu satu rumus luas segitiga, satu rumus luas persegi, dan kedua rumus luas persegi panjang. Pada constructing the target, KJT menjumlahkan luas segitiga, luas persegi, dan luas persegi panjang. Pada tahap determining equivalence, KJT yakin jawabannya sudah benar karena NRM sudah menghitung dengan tepat luas segitiga, luas persegi, dan luas persegi panjang, sehingga keseluruhan hasil tersebut adalah $454 \mathrm{~m}^{2} 54 \mathrm{~m}^{\wedge} 2$.

2. Translasi Representasi Visual ke Verbal

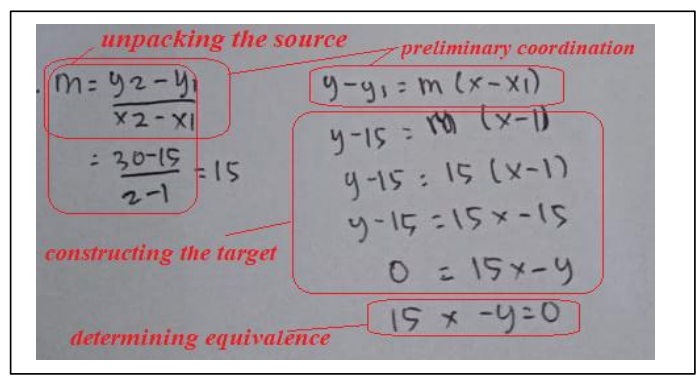

Gambar 8. Jawaban KJT Soal Nomor 2 
Pada unpacking the source, KJT mengungkapkan informasi awal yang terdapat pada grafik yaitu titik $x_{1}=1, y_{1}=15, x_{2}=2, y_{2}=30$. Pada preliminary coordinator, KJT menuliskan rumus untuk menentukan persaman grafik dengan mencari gradien terlebih dahulu. Pada constructing the target, KJT mencari gradien dengan titik yang diketahui $x_{1}=1, y_{1}=15, x_{2}=2, y_{2}=30$, kemudian KJT memasukkan nilai gradien pada rumus yang telah ditulis untuk menentukan persamaan grafik $y-y_{1}=$ $m\left(x-x_{1}\right)-y_{-} 1=m x-x_{-}$. 1 . Pada determining equivalence, KJT yakin jawaban $0=15 x-y=15 \mathrm{x}-\mathrm{y}$ karena KJT telah memeriksa kembali jawabannya dengan memasukkan $x=1=1$ ada persamaan $0=$ $15 x-y=15 x-y e n u n j u k k a n$ nilai $y=15=15$

3. Translasi Representasi Verbal ke Visual

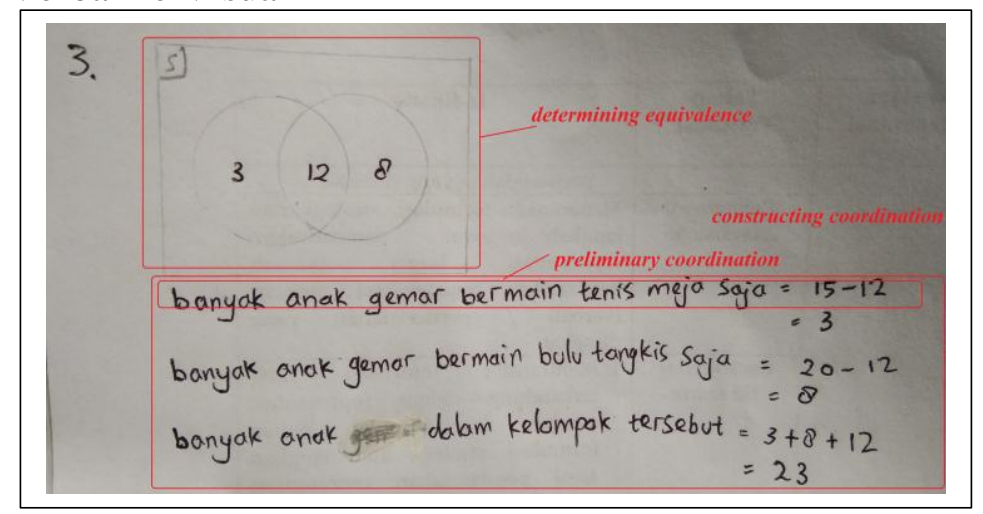

Gambar 9. Jawaban KJT Soal Nomor 3

Pada unpacking the source, KJT tidak menuliskan informasi yang terdapat dalam soal namun KJT mengungkapkan 155 ak gemar bermain bulu tangkis, 200 ak gemar bermain tenis meja dan 122anak gemar bermain keduanya. Pada preliminary coordinator, KJT menggambar diagram Venn dan menghitung banyak anak yang gemar bermain bulu tangkis saja, menghitung banyak anak yang gemar bermain tenis meja saja dan menghitung banyak anak dalam kelompok tersebut. Pada constructing the target, KJT menuliskan banyak anak gemar bermain keduanya adalah 12, sehingga banyak anak gemar bermain bulu tangkis saja $=15-12=315-12=3$ anak gemar bermain tenis meja saja $=20-12=$ 820-12=8banyak anak dalam kelompok tersebut $=3+8+12=233+8+12=23$ determining equivalence, KJT yakin dengan jawabannya diagram Venn dan banyaknya anak dalam kelompok tersebut sudah benar. Karena KJT telah menghitung dengan tepat sesuai bilangan-bilangan yang diketahui.

4. Translasi Representasi Verbal ke Simbolik

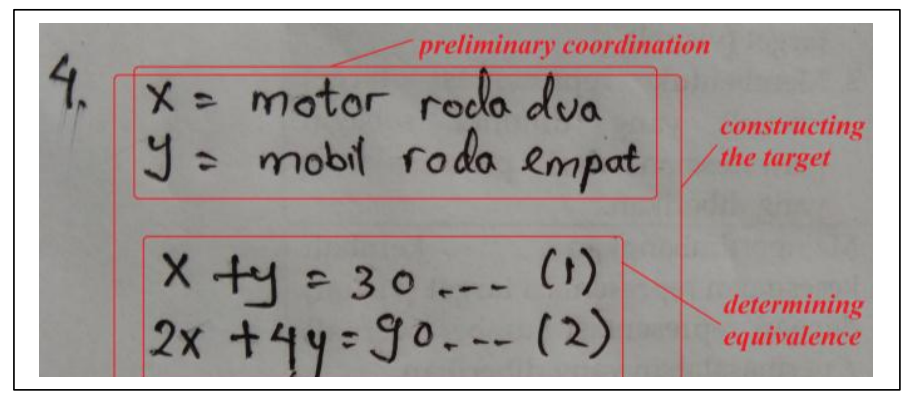

Gambar 10. Jawaban KJT Soal Nomor 4 
Pada unpacking the source, KJT tidak menuliskan kembali informasi namun KJT menyebutkan informasi awal pada saat wawancara bahwa tempat parkir untuk motor roda dua dan mobil roda empat dapat menampung 300buah kendaraan, jumlah roda seluruh kendaraan 900 ah. Jika motor dinyatakan dengan $x$ dan mobil dinyatakan dengan $y$. Pada preliminary coordinator, KJT menyatakan $x$ ebagai motor roda dua dan y sebagai mobil roda empat, kemudian membentuk sistem persamaan linear dua variabel. Pada constructing the target, KJT menyebutkan $x+y=30+\mathrm{y}=30$ i pernyataan pertama, kemudian $2 x+4 y=90 \mathrm{x}+4 \mathrm{y}=90 \mathrm{i}$ pernyataan kedua. Pada tahap determining equivalence, KJT yakin sistem persamaan linear dua variabel sudah benar, karena telah mengerjakan sesuai dengan apa yang dinyatakan dalam soal.

5. Translasi Representasi Simbolik ke Visual

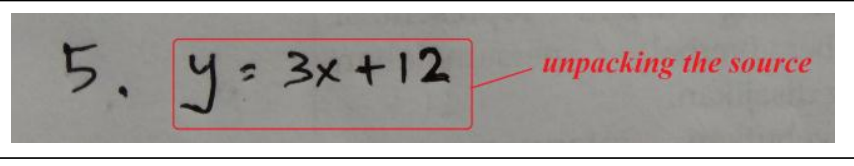

Gambar 11. Jawaban KJT Soal Nomor 5

Pada unpacking the source, KJT menuliskan informasi yang diketahui pada soal yaitu persamaan garis harga beras $y=3 x+12=3 \mathrm{x}+12$ preliminary coordination, KJT tidak menuliskan jawaban karena KJT menganggap tidak terdapat titik koordinat pada soal tersebut. Oleh sebab itu, KJT tidak dapat menyelesaikan soal nomor 5 ini.

6. Translasi Representasi Simbolik ke Verbal

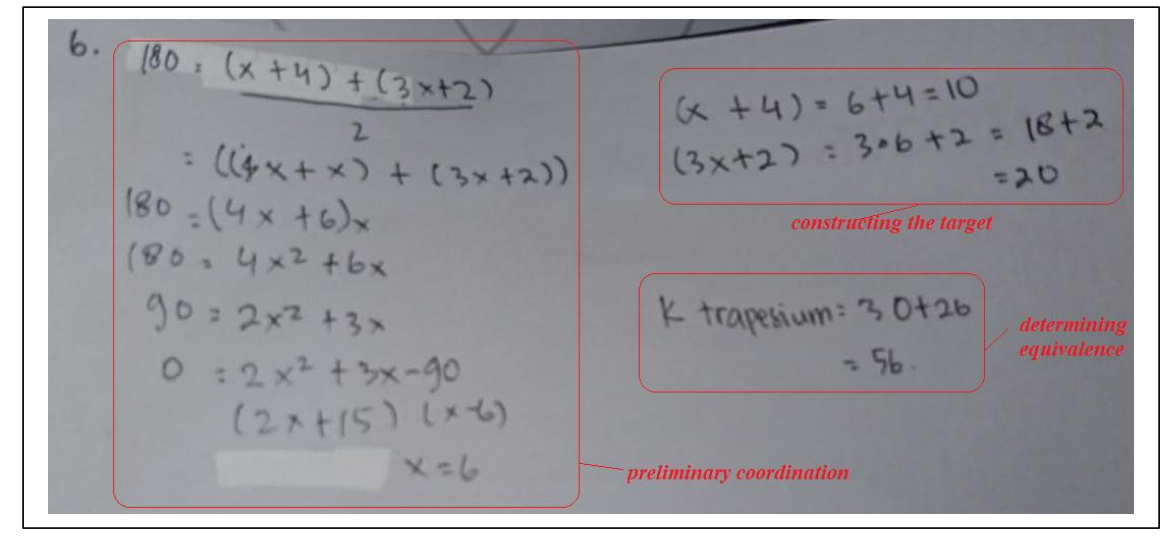

\section{Gambar 12. Jawaban KJT Soal Nomor 6}

Pada unpacking the source, KJT tidak menuliskan kembali informasi yang diketahui pada soal namun mengungkapkannya saat wawancara yaitu panjang sisi-sisi sejajar $(x+4) m x+4) \mathrm{m}(3 x+$ 2) $m 3 x+2) m$ kedua garis sejajar $2 x m 2 x$ mdan luas taman $180 m^{2} 80 \mathrm{~m}^{\wedge} 2$, kemudian soal diminta untuk menentukan keliling taman berbentuk trapesium sama kaki. Pada preliminary coordination, KJT menuliskan langkah awal untuk menentukan keliling taman trapesium sama kaki dengan mencari nilai $x$ ari luas taman kemudian substitusi nilai $x$ ada panjang sisi-sisi sejajar $(x+4) m x+4) \mathrm{m}(3 x+$ 2) $m 3 x+2)$ mjarak kedua garis sejajar $2 x m 2 x m n$ mencari sisi-sisi miring trapesium sama kaki menggunakan Pythagoras. Pada constructing the target, KJT mendapat nilai $x$ itu 6 yang kemudian substitusi nilai $x=6=6(x+4)$ dan hasilnya 10 , substitusi nilai $x=6=6 \mathrm{e}(3 x+2) 3 \mathrm{x}+2)$ silnya 20 , selanjutnya mencari sisi miring trapesium dengan cara Pythagoras dan hasilnya 13, sehingga panjang 
sisi-sisi trapesium 10,20,13,130, 20,13, 13kan diperoleh keliling taman trapesium tersebut $56 \mathrm{~m}^{2}$. Pada tahap determining equivalence, KJT yakin dengan jawaban keliling taman trapesium tersebut $56 \mathrm{~m}^{2}$ sudah benar karena KJT telah menghitung dengan tepat dan sesuai yang diminta soal.

\section{PEMBAHASAN}

Berdasar pada hasil analisis dari tugas translasi representasi matematis dan wawancara, diperoleh deskripsi dari kemampuan translasi representasi matematis siswa sebagai berikut.

Tabel 4. Tabel Hasil Analisis Kemampuan Translasi Representasi Matematis

\begin{tabular}{|c|c|c|c|c|c|c|c|}
\hline \multirow{2}{*}{ Subjek } & \multirow{2}{*}{$\begin{array}{c}\text { Indikator translasi representasi } \\
\text { matematis }\end{array}$} & \multicolumn{6}{|c|}{ No. Soal } \\
\hline & & 1 & 2 & 3 & 4 & 5 & 6 \\
\hline \multirow{4}{*}{ NRM } & Unpacking The Source (1.1\&1.2) & $\sqrt{ }$ & $\sqrt{ }$ & $\sqrt{ }$ & $\sqrt{ }$ & $\sqrt{ }$ & $\sqrt{ }$ \\
\hline & Preliminary Coordination (2.1) & $\sqrt{ }$ & $\sqrt{ }$ & $\sqrt{ }$ & $\sqrt{ }$ & $\sqrt{ }$ & $\sqrt{ }$ \\
\hline & Construction The Target (3.1) & $\sqrt{ }$ & $\sqrt{ }$ & $\sqrt{ }$ & $\sqrt{ }$ & $\sqrt{ }$ & $\sqrt{ }$ \\
\hline & Determining Equivalence (4.1) & $\sqrt{ }$ & $\sqrt{ }$ & $\sqrt{ }$ & $\sqrt{ }$ & $\sqrt{ }$ & $\sqrt{ }$ \\
\hline \multirow{4}{*}{ KJT } & Unpacking The Source (1.1\&1.2) & $\sqrt{ }$ & $\sqrt{ }$ & $\sqrt{ }$ & $\sqrt{ }$ & $\sqrt{ }$ & $\sqrt{ }$ \\
\hline & Preliminary Coordination (2.1) & $\sqrt{ }$ & - & $\sqrt{ }$ & $\sqrt{ }$ & $\sqrt{ }$ & $\sqrt{ }$ \\
\hline & Construction The Target (3.1) & $\sqrt{ }$ & - & $\sqrt{ }$ & $\sqrt{ }$ & $\sqrt{ }$ & $\sqrt{ }$ \\
\hline & Determining Equivalence (4.1) & $\sqrt{ }$ & - & $\sqrt{ }$ & $\sqrt{ }$ & $\sqrt{ }$ & $\sqrt{ }$ \\
\hline
\end{tabular}

Tabel 4 menunjukkan bahwa setiap soal translasi representasi yang dikerjakan oleh salah satu siswa telah sesuai dengan tahap translasi representasi, yaitu unpacking the source, preliminary coordination, construction the target, dan determining equivalence, sedangkan siswa yang lain mendapat kesulitan dalam pengerjaan, terutama pada translasi representasi simbolik ke visual tahap preliminary coordination, construction the target, dan determining equivalence.

1. Unpacking The Source

Tahap unpacking the source terdapat dua indikator. Indikator pertama yaitu siswa menyebutkan informasi yang terkandung dalam representasi sumber, sedangkan indikator kedua yaitu menyebutkan representasi target yang diminta berdasarkan representasi sumber. Pada tahap unpacking source, kedua siswa dapat memahami soal kontekstual yang diberikan dengan menyebutkan hal-hal yang diketahui pada keenam soal dalam bentul verbal, simbolik, dan visual. Hal ini sesuai dengan pendapat Nurlatifah, Sudin and Maulana (2017) bahwa masalah kontekstual dapat mengkonstruksi pemahaman siswa. Farhan and Zulkarnain (2019) juga menambahkan bahwa konsep matematika yang dimiliki oleh siswa dapat memberikan kemudahan peserta didik untuk memahami masalah, merancang strategi penyelesaian, dan menyelesaikan masalah secara terstruktur dan tersistematis. Oleh karena itu siswa dapat menyebutkan informasi yang ada pada soal kontekstual baik diperlukan maupun yang tidak diperlukan.

2. Preliminary Coordination

Tahap preliminary coordination memiliki indikator yaitu menentukan strategi atau langkah awal pembentukan representasi target berdasarkan representasi sumber. Pada tahap preliminary coordination, salah satu siswa dapat menentukan apa yang harus dilakukan pertama kali untuk membentuk representasi target dengan menggunakan informasi awal. Hal ini terlihat pada hasil pengerjaan dan wawancara. Siswa tersebut dapat menentukan langkah awal pembentukan representasi target, membuat pemisalan untuk 
membentuk representasi simbolik, menentukan langkah awal pembentukan tabel dan grafik atau representasi visual, dan memperkirakan representasi verbal berupa soal kontekstual yang berkaitan dengan informasi yang diberikan. Hal ini sesuai dengan pendapat Bossé, Adu-Gyamfi and Chandler (2014) bahwa siswa dapat mengenali ide matematika dan menghubungkan informasi yang ada pada representasi awal dan representasi target. Sedangkan siswa yang lain kesulitan untuk menentukan langkah yang akan dikerjakan pada translasi representasi visual ke simbolik dan cenderung tidak dapat memahami informasi yang penting yang terdapat diantara kedua representasi. Hal ini akan berpengaruh pada proses pembentukan representasi target untuk menyelesaikan persoalan.

\section{Construction The Target}

Tahap constructing the target memiliki indikator yaitu membentuk representasi target yang diminta sebagai penyelesaian dari representasi sumber. Pada tahap constructing the target, salah satu siswa dapat menyelesaikan masalah sesuai dengan representasi target yang dibuat dengan mengolah informasi yang tersedia pada representasi sumber. Hal ini terlihat dari langkah pembentukan representasi target dengan menggunakan representasi sumber dari setiap translasi representasi. Sedangkan siswa yang lain tidak dapat menyelesaikan soal kontekstual pada translasi representasi simbolik ke visual karena kesalahan pada tahap preliminary coordination. Hal ini sesuai dengan pendapat Bossé, Adu-Gyamfi and Chandler (2014) bahwa siswa cenderung terganggu menyelesaikan soal dikarenakan mikro-konsep yang membingungkan.

4. Determining equivalence

Tahap determining equivalence memiliki indikator yaitu mempertimbangkan kembali kesesuaian representasi target dengan representasi sumber. Pada tahap determining equivalence, kedua siswa telah melakukan pemeriksaan kembali. Mereka memeriksa kembali jawaban yang diperoleh dengan menyesuaikan informasi pada representasi target dengan representasi sumber. Hal ini sesuai dengan pendapat Sternberg dalam Marliyanti and Amin (2016) bahwa pada tahap determining equivalence dapat dilakukan dengan selective comparison, yaitu dengan membandingkan hubungan yang diperoleh pada representasi target dan informasi awal. Kemudian tahap determining equivalence pada translasi representasi simbolik ke visual yang tidak dapat diselesaikan oleh satu siswa, karena kesalahan pada tahap preliminary coordination.

\section{SIMPULAN}

Berdasar ada hasil dan pembahasan dalam penelitian ini yaitu pada hasil tes kemampuan translasi representasi matematis siswa SMP, dapat diperoleh simpulan bahwa siswa dapat menyelesaikan soal kontekstual pada translasi representasi visual ke representasi verbal, translasi representasi verbal ke representasi visual, translasi representasi simbolik ke representasi visual, translasi representasi verbal ke representasi simbolik, translasi representasi simbolik ke representasi verbal. Namun, kemampuan translasi representasi matematis siswa SMP dalam menyelesaikan soal kontekstual pada translasi representasi visual ke representasi simbolik tidak dapat terselesaikan dengan tepat dikarenakan kesalahan pada tahap preliminary coordination yang tidak dapat menentukan langkah awal yaitu titik koordinat pada grafik untuk pembentukan representasi target berdasarkan representasi sumber.

Berdasar ada hasil penelitian yang telah dilakukan, maka peneliti memberikan saran sebagai berikut:

1) Bagi peneliti lain, sebelum siswa mengerjakan soal yang disediakan hendaknya siswa diberi informasi terkait indikator kemampuan translasi representasi matematis, kemudian saat wawancara dapat mengkonstruksi pertanyaan wawancara dengan baik untuk mendalami kemampuan translasi representasi matematis, sehingga mempermudah dalam analisis data; 2) Diharapkan guru dapat memberikan banyak 
latihan soal translasi representasi pada siswa, agar siswa termotivasi dalam menyelesaikan soal yang ada kaitannya dengan berbagai bentuk representasi.

\section{DAFTAR RUJUKAN}

Arifin, M. Z. (2017). Kemampuan Translasi Antar-Representasi Matematika Siswa MTs Ditinjau dari Gender (Tesis tidak diterbitkan). Universitas Negeri Surabaya, Surabaya.

Bossé, M., Adu-Gyamfi, K. and Chandler, K. (2014). Students' Differentiated Translation Processes. International Journal for Mathematics Teaching and Learning, (828), pp. 1-28. doi: https://pdfs.semanticscholar.org/4443/7897b6312821fb2513644254808318d46fbf.pdf?_ga=2.18925 $8155.1291256576 .1592806255-284283676.1592806255$.

Fadillah, S. (2011). Meningkatkan Kemampuan Representasi Multipel Matematika Siswa SMP Melalui Pembelajaran Dengan Pendekatan Open Ended, Jurnal Pendidikan Matematika, 2(2), pp. 100-107. doi: http://dx.doi.org/10.36709/jpm.v2i2.1966.

Faisal, S. (2007). Format-format Penelitian Sosial. Jakarta: Raja Grafindo Persada.

Farhan, M. and Zulkarnain, I. (2019). Analisis Kesalahan Mahasiswa pada Mata Kuliah Kalkulus Peubah Banyak Berdasarkan Newmann 's Error Analysis. Jurnal Kajian Pendidikan Matematika, 4(2), pp. 121-134. doi: http://dx.doi.org/10.30998/jkpm.v4i2.3843.

Fennell, F. and Rowan, T. (2001). Representation: An important process for teaching and learning mathematics. Teaching Children Mathematics, 7(5), pp. 288-292. doi: https://www.researchgate.net/publication/234581020_Representation_An_Important_Process_for_T eaching_and_Learning_Mathematics.

Hidayati, S. L. N., Hudiono, B. and Nursangaji, A. (2014). Kemampuan Translasi dan Transformasi Representasi dalam Menyelesaikan Soal Persamaan Linier Satu Variabel Di SMP. Jurnal Pendidikan dan Pembelajaran Khatulistiwa, 3(1), pp. 1-18. http://jurnal.untan.ac.id/index.php/jpdpb/article/view/4201.

Kemdikbud (2014). Peraturan Mendikbud Nomor 58 tahun 2014 tentang Kurikulum 2013 Sekolah Menengah Pertama (SMP) / Madrasah Tsanawiyah (MTs). Jakarta: Kementerian Pendidikan dan Kebudayaan. doi: https://buku.yunandracenter.com/produk/permendikbud-2014-058-peraturan-582014-tentang-kurikulum-2013-smpmts/.

Marliyanti, D. and Amin, S. M. (2016). Kemampuan Translasi Antar Representasi Matematika Siswa Dalam Memecahkan Masalah Sistem Persamaan Linear Dua Variabel Ditinjau Dari Kemampuan Matematika. Jurnal MATHEdunesa, 3(5), pp. 92-101. doi: https://jurnalmahasiswa.unesa.ac.id/index.php/mathedunesa/article/view/18516.

Monika, A. (2015). Kemampuan Translasi Representasi Matematis Siswa Materi Himpunan di SMP. Jurnal Pendidikan dan Pembelajaran Khatulistiwa, 4(12), pp. 1-11. doi: 
http://jurnal.untan.ac.id/index.php/jpdpb/article/view/12657.

Nurlatifah, D., Sudin, A. and Maulana, M. (2017). Perbedaan Pengaruh Antara Pendekatan Realistik dan Pendekatan Kontekstual Terhadap Pemahaman Matematis Siswa Pada Materi Kesebangunan. Jurnal Pena Ilmiah, 2(1), pp. 961-970. https://ejournal.upi.edu/index.php/penailmiah/article/view/11233/6854.

Sandie. (2020). Karakterisasi Translasi Representasi Mahasiswa dalam Menyelesaikan Masalah Kovariasional (Doctoral dissertation). Universitas Negeri Malang, Malang. Retrieved from: http://repository.um.ac.id/id/eprint/115624.

Tandiseru, S. R. (2015). Efektifitas Pendekatan Kontekstual Budaya Lokal Terhadap Pencapaian Kemampuan Representasi Matematis Siswa SMP. Jurnal KIP, 3(3), pp. 675-683. doi: https://docplayer.info/71131265-Efektifitas-pendekatan-kontekstual-budaya-lokal-terhadappencapaian-kemampuan-representasi-matematis-siswa-smp.html. 